\title{
PEMBUATAN PROTOTIPE INSTALASI UJI METER AIR ELEKTRONIK TIPE VERTIKAL METODE GRAVIMETRIK DAN PENGARUH KEKERUHAN TERHADAP AKURASI PENGUKURAN
}

\author{
DUDI ADI FIRMANSYAH *, VERA FIRMANSYAH, DECKY ARI IRWANTO, ADIB \\ AZZALUULY, RAIKHAN ZULBAHRI
}

Program Studi D3 Metrologi dan Instrumentasi, Akademi Metrologi dan Instrumentasi Jl. Daeng Muhammad Ardiwinata km 3,4 Cihanjuang Bandung Barat 40559, Jawa Barat, Telp. 022-6611054

*email : dudiaf1983@gdrivepro.com

\begin{abstract}
Abstrak. Meter air merupakan alat ukur yang digunakan untuk menunjukan jumlah volume air atau laju alir dari fluida yang dialirkan melalui saluran pipa. Agar dapat menunjukan hasil pengukuran yang akurat, meter air harus dikalibrasi dengan memenuhi semua kondisi yang dipersyaratkan, termasuk di dalamnya kondisi air uji yang digunakan di dalam instalasi uji. Sesuai dengan Rekomendasi OIML R 49-2, air uji tersebut harus memenuhi persyaratan air minum, tidak mengandung bahan yang dapat merusak meter air dan berbahaya bagi manusia. Salah satu parameter kualitas air yang dapat merusak meter air adalah tingkat kekeruhan. Untuk menguji parameter kekeruhan, prototipe instalasi uji dibuat agar dapat mengukur kekeruhan dan mengalirkan air uji secara vertikal menuju meter air lalu air keluarannya ditimbang pada suhu tertentu untuk diubah menjadi volume dan dibandingkan dengan volume dari meter air. Prototipe ini menggunakan berbagai sensor dan hasil kalibrasinya menunjukan tingkat akurasi dan presisi yang tinggi yaitu sensor loadcell $99,8 \%$ dan $99,9 \%$; sensor volume $95,4 \%$ dan 93,6\%; sensor suhu 96,3\% dan 95,9\%; dan sensor kekeruhan dengan tingkat kesalahan $0,5 \%$ dan RSD 3,3\%. Hasil pengujian pada meter air digital tipe vertikal menunjukan peningkatan tingkat kesalahan dari $0,5 \%$ menjadi 3,0\% dan 4,7\% pada saat kekeruhan dinaikan dari 17,1 NTU (air bersih) menjadi 36,9 NTU dan 95,6 NTU melalui penambahan tanah pada air uji. Efek kekeruhan lebih terlihat saat menggunakan densitas hidrometer, peningkatan tingkat kesalahan dari $0,9 \%$ menjadi $4,5 \%$ dan $7,2 \%$ teramati.
\end{abstract}

Kata kunci: meter air, kekeruhan, instalasi uji, ditimbang, air uji

\begin{abstract}
A water meter is an instrument to measure the total volume or flow rate of a fluid that flows through a pipeline. To yield accurate measurements, a water meter must be calibrated in prerequisite conditions, including the testing water utilized in the testing installation. As regulated at International Recommendation OIML R 49-2, this water should fulfill the drinking water requirements, not containing the substance that can affect the meter and harmful for the human. One of those parameters is the turbidity. For testing it, a prototype of testing installation is fabricated that able to measure the turbidity and allow the water to flow vertically through the water meter and weight it at certain temperature to be converted as volume and compared with the measured volume from the water meter. This prototype employed several sensors and their calibration results are in a high level of accuracy and precision e.g. load cell sensor about 99,8\% and 99,9\%; volume sensor about $95,4 \%$ and $93,6 \%$; temperature sensor about $96,3 \%$ and $95,9 \%$; and turbidity sensor about $0,5 \%$ error and RSD of 3,3\%. Testing results for the electronic water meter of the vertical type show an increase of the error level from $0,5 \%$ to $3,0 \%$ and $4,7 \%$ when turbidity level is increased from 17,1 NTU (clean water) to 36,9 NTU and 95,6 NTU by addition of soils to the testing water. Turbidity effect are more visible
\end{abstract}


when using the measured density from the hydrometer, an increased error level from $0,9 \%$ to $4,5 \%$ and $7,2 \%$ are observed.

Keywords: water meter, turbidity, testing installation, weighing, testing water

\section{Pendahuluan}

Air merupakan kebutuhan yang sangat penting bagi semua makhluk hidup terutama bagi manusia untuk berbagai keperluan mulai dari minum, masak, mandi mencuci, rekreasi, transportasi hingga pembangkit energi listrik [1], [2]. Dengan semakin bertambahnya jumlah penduduk, kebutuhan air pun semakin meningkat [3], [4]. Akan tetapi, sumber air bersih alami terutama yang berasal dari sumur dan mata air semakin sulit diperoleh, sehingga sebagian pasokan air bersih harus diproses dari air permukaan seperti dari sungai atau danau [3]. Proses tersebut biasanya dilakukan oleh PDAM dan produk air bersih tersebut kemudian didistribusikan kepada penduduk yang membutuhkan [1]. Selanjutnya, penduduk membayar retribusi air kepada PDAM atas volume air yang digunakan dari penunjukan alat ukur yang dikenal dengan meter air [4], [5]. Oleh karenanya, meter air kemudian digolongkan menjadi alat Ukur, Takar, Timbang dan Perlengkapannya (UTTP) yang wajib ditera ulang atau dikalibrasi ulang sesuai dengan amanat UndangUndang Nomor 2 Tahun 1981 tentang Metrologi Legal.

Meter air adalah alat yang digunakan untuk mengukur banyaknya air secara terusmenerus melalui sistem kerja peralatan yang dilengkapi dengan sensor, unit penghitung, dan unit pengukur untuk menyatakan volume air yang lewat [6]. Dikarenakan fungsinya tersebut, meter air harus dijamin kebenaran pengukurannya agar tidak merugikan konsumen dan PDAM [5]. Meter air yang akurat akan menjadi jaminan bagi konsumen dari kesalahan pembayaran retribusi air, sedangkan bagi PDAM, meter air yang akurat akan menghindarkan dari kerugian akibat volume air yang tidak terhitung, kebocoran/kehilangan air dan pencurian air [4], [7]. Meskipun potensi kerugian dari satu meter air rumah tangga yang tidak akurat tidak signifikan dibandingkan dengan kapasitas produksi air bersih PDAM, akan tetapi apabila kerugian tersebut diakumulasikan untuk seluruh pelanggan di wilayah tertentu dan dalam jangka waktu yang lama, maka kerugian tersebut akan signifikan bagi PDAM [7]-[9]. Untuk mengatasi hal tersebut, meter air yang beredar harus dipastikan kebenaran pengukurannya melalui pengujian meter air yang akurat dan seragam agar dapat diterima oleh kedua belah pihak, yaitu PDAM dan konsumen [5]. Oleh karenanya, meter air dan pengujiannya kemudian diatur oleh negara melalui Keputusan Direktur Jenderal Standardisasi dan Perlindungan Konsumen (Dirjen SPK) Nomor 133/SPK/KEP/10/2015 tentang Syarat Teknis Meter Air.

Pengujian meter air dilakukan dengan menggunakan instalasi pengujian meter air atau test bench yang cara kerjanya adalah dengan membandingkan volume aliran air yang terukur oleh meter air dengan volume bejana ukur standar sebagai standar pengukurannya, atau dengan master meter, atau dengan hasil penimbangan [6], [10]. Untuk mendapatkan hasil pengujian meter air yang memiliki akurasi tinggi dan dapat dipertanggungjawabkan, maka semua kondisi terkait dengan pengujian harus dijaga agar selalu memenuhi ketentuan [6], [11]. Salah satu persyaratan pengujian meter air yang sangat penting adalah seperti yang dinyatakan di dalam Rekomendasi Internasional OIML R 49-2 yaitu air uji harus memenuhi persyaratan air minum, tidak mengandung bahan yang dapat merusak meter air, tidak 
mengandung gelembung udara, dan jika menggunakan air yang didaur ulang, air yang tersisa di dalam meter tidak boleh berbahaya bagi manusia [11].

Meskipun persyaratan kualitas air uji cukup ketat, akan tetapi kenyataan di lapangan menunjukan fakta yang berbeda karena ditemukan air yang keruh di instalasi uji meter air di kantor unit metrologi daerah kabupaten/kota [12]. Hal ini tentu saja dapat mempengaruhi kebenaran hasil pengujian meter air. Terkait dengan pengaruh kekeruhan atau konsentrasi partikulat dan pengendapan terhadap akurasi meter air, beberapa penelitian telah dilakukan [13]-[15]. Pada tahun 2005, Arregui mengamati beberapa faktor yang mempengaruhi akurasi meter air diantaranya pengendapan partikulat yang dapat menyebabkan kelebihan pembacaan meter air pada kondisi laju alir menengah dan laju alir tinggi, sedangkan pada laju alir rendah menyebabkan pembacaan meter air menjadi lebih kecil. Pada tahun 2011, Mutikanga [14] menemukan bahwa hampir 75\% kegagalan pengukuran pada meter air volumetrik di kota Kampala disebabkan oleh partikulat. Namun, besarnya konsentrasi partikulat atau kekeruhannya yang menyebabkan kegagalan tersebut tidak dijelaskan pada studi tersebut [13], [14].

Pada tahun 2012, Buck [15] meneliti efek kekeruhan pada akurasi beberapa jenis meter air dan menemukan bahwa meter air tipe osilasi piston yang paling besar dampaknya dari pemasukan suspensi pasir tersebut sedangkan meter air tipe multijet dan osilasi fluida paling dapat mentoleransi efek pasir tersebut. Akan tetapi, studi ini hanya memasukan suspensinya di awal percobaan sehingga kekeruhannya tidak konstan dan data ini tidak dapat dijadikan acuan apabila efek kekeruhannya berlangsung lama dengan kekeruhan yang konstan, karena di lapangan kekeruhan ini dapat berlangsung cukup lama yang diakibatkan oleh masuknya tanah ke dalam pipa yang bocor [16], [17]. Sedangkan di sisi lain, sistem pengukuran kekeruhan air dan kualitas air telah berkembang cukup pesat yang dapat menginformasikan kekeruhan dan parameter kualitas air lainnya dengan secara online dan real time [18], [19].

Selain itu, meter air yang semula bekerja secara analog mulai dikembangkan menjadi berbentuk digital [20]. Hal ini dikarenakan kemudahannya untuk pencatatan pemakaian meter air secara digital yang dapat ditransmisikan langsung ke PDAM [21], atau dapat dipantau melalui aplikasi yang terhubung dengan internet [22]. Selain itu, pengukuran dengan alat ukur analog banyak menunjukan hasil yang kurang akurat [23]. Salah satu jenis meter air digital yang banyak digunakan adalah yaitu K-24 water flow meter yang banyak digunakan sebagai meter air komersial [24] dan pengukur volume atau debit di dalam sistem pengolah air bersih [25]. Oleh karenanya, pada penelitian ini akan dibuat prototipe instalasi uji meter air digital yang dapat mengukur kekeruhan air uji dan dapat menentukan akurasi meter air dalam waktu bersamaan. Batasan kondisi kekeruhan terhadap akurasi meter air dan batas kekeruhan air yang dapat mengganggu operasional meter air juga belum ditemukan baik di dalam peraturan atau maupun syarat teknis meter air yang ada [6]. Instalasi uji meter air yang ada selama ini hanya fokus pada kebenaran pengukuran meter air, sehingga prototipe instalasi uji meter air yang dapat menguji pengaruh kualitas air terhadap akurasi meter air menjadi sangat diperlukan, mengingat beragamnya tingkat kekeruhan air yang diproses dan dihasilkan oleh PDAM.

\section{Metode Penelitian}

Penelitian ini dibagi menjadi 3 (tiga) tahap yaitu (1) pembuatan prototipe, (2) kalibrasi sensor, dan (3) pengujian meter air. Prototipe yang dibuat adalah prototipe 
instalasi uji meter air untuk pengujian parameter kekeruhan. Pada tahap pertama, berbagai sensor yang digunakan (sensor loadcell $10 \mathrm{~kg}$, sensor ultrasonic HC-SR04 sebagai sensor level/volume, 2 (dua) unit sensor suhu (MAX6675 K-Type Thermocouple for Aduino), dan sensor kekeruhan (Turbidity Sensor SKU SEN0189)) disusun untuk wadah atas dan wadah bawah, lalu dihubungkan dengan mikrokontroler lalu diproses menjadi penunjukan level,volume, kekeruhan dan suhu pada LCD Wadah Atas; serta penunjukan massa, suhu, densitas, dan volume densitas pada LCD Wadah Bawah. Hubungan antar sensor, mikrokontroler dan LCD ditunjukan pada Gambar 1. Susunan sensor tersebut yang digabung dengan komponen lainnya ditunjukan pada rancangan prototipe pada Gambar 2. Prototipe ini terdiri 2 (dua) tempat penampung air yaitu wadah atas dan wadah bawah. Sensor suhu, sensor level/volume, dan sensor kekeruhan digunakan untuk mengukur suhu, level / volume air dan kekeruhan air uji di wadah atas. Sinyal dari sensor tersebut dikirimkan ke mikrokontroler untuk ditampilkan sebagai level, volume, kekeruhan dan suhu dari air di dalam wadah atas pada LCD di sebelah kiri. Sensor loadcell dan sensor suhu digunakan untuk mengukur massa dan suhu air yang dialirkan dari meter air uji, lalu sinyalnya dikirimkan ke mikrokontroler untuk diproses menjadi massa, suhu, densitas yang dihitung dari persamaan densitas air [26], dan volume densitas (Vol. Rho) yang dihitung dari pembagian massa dengan densitas dari suhu terukur.

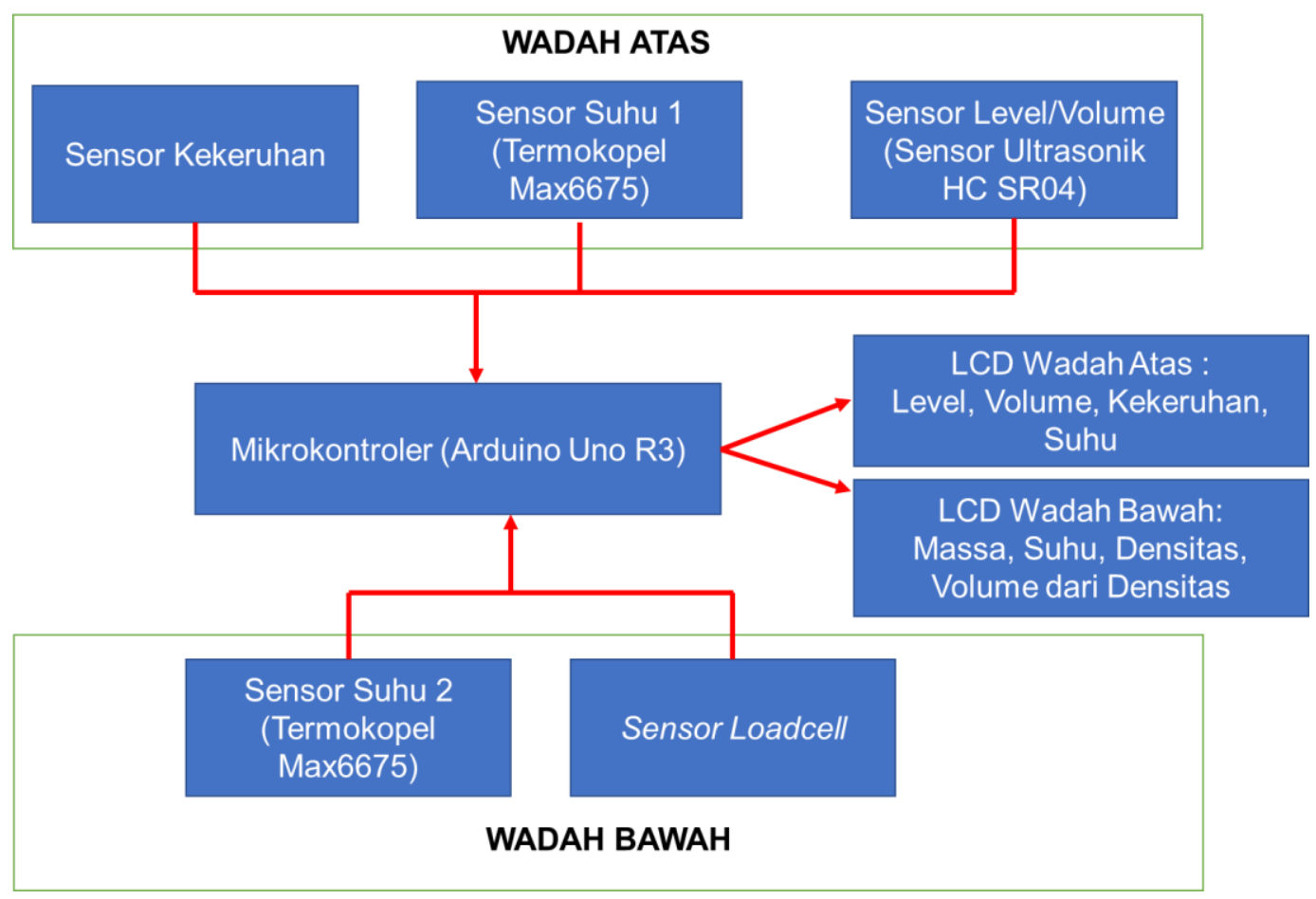

Gambar 1. Diagram blok prototipe instalasi uji meter air untuk pengujian pengaruh kekeruhan

Pada tahap kedua, sensor-sensor pada prototipe dikalibrasi. Pertama, sensor loadcell dikalibrasi dengan cara penentuan faktor kalibrasi yang disesuaikan dengan massa sebenarnya dari anak timbangan yang ditimbang dan penentuan akurasi, presisi dan histerisis dengan mencatat hasil penimbangan terhadap anak timbangan standar (anak timbangan kelas M3). Kedua, sensor suhu dikalibasi dengan campuran air-es 
[27] dengan mencatat penunjukan suhu dari prototipe dan termometer digital standar. Ketiga, sensor level/volume dikalibrasi terhadap pengukuran ketinggian (dengan mencatat pengukuran ketinggian dari prototipe dan pengukuran tinggi dari penggaris komersial sebagai standar), pengukuran ketinggian cairan pada saat ditambahkan air per liter pada prototipe untuk dibuat menjadi kurva kalibrasi volume terhadap ketinggian, lalu pengukuran volume air yang ditambahkan pada prototipe. Penentuan tingkat akurasi dan presisi dari ketiga sensor tersebut ditentukan dari nilai bias dan standar deviasi, sedangkan nilai histerisis ditentukan dari selisih output pengukuran saat kondisi pengukuran naik dan pengukuran turun [28].

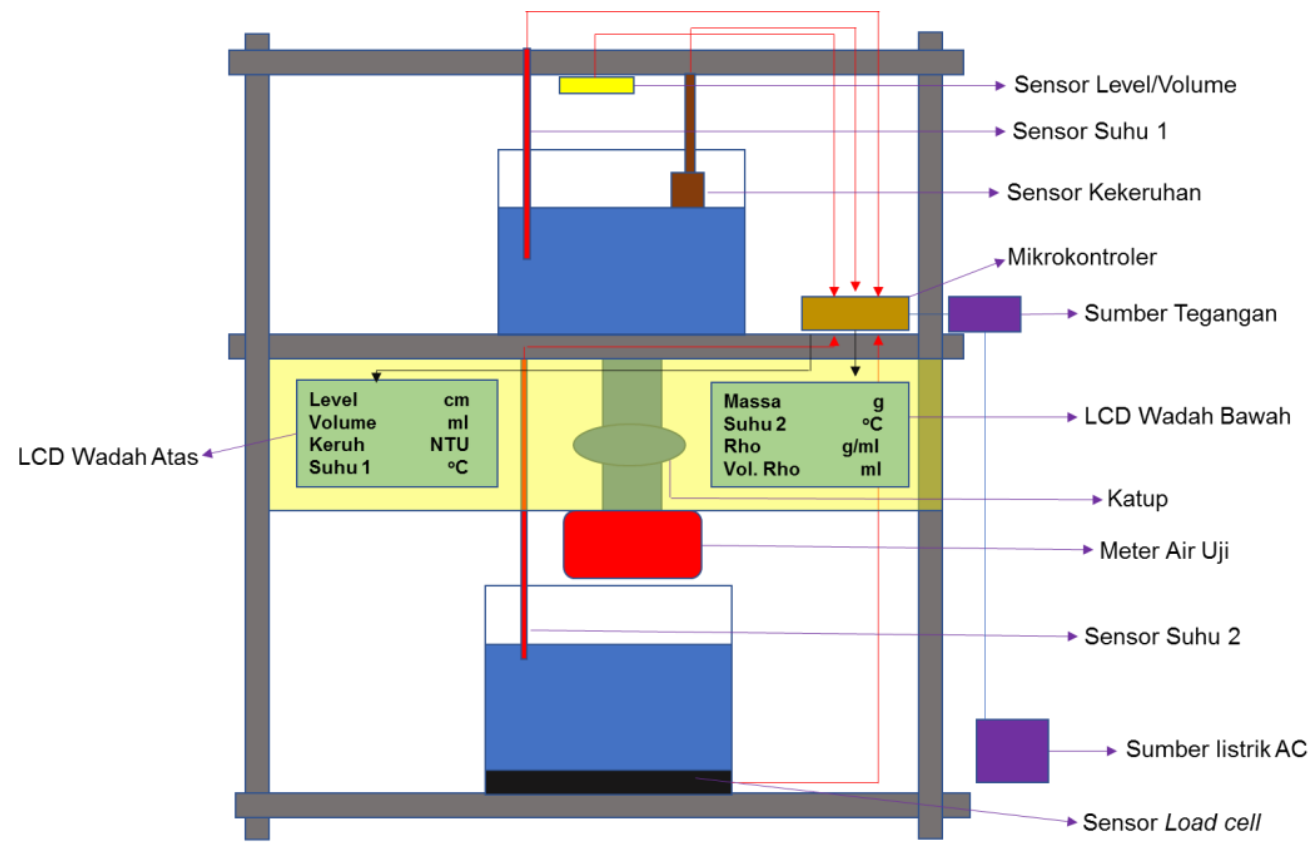

Gambar 2. Rancangan prototipe

Keempat, sensor kekeruhan dikalibrasi dengan larutan standar kekeruhan yaitu Larutan 0 NTU (aquades), serta Larutan 100 NTU dan Larutan 400 NTU yang dibuat dari hidrazin sulfat dan heksametilen tetraamine [29]. Kalibrasi sensor kekeruhan dilakukan dengan mengukur tegangan keluaran sensor dari larutan standar kekeruhan, lalu kurva kalibrasi tegangan-kekeruhan dibuat dan persamaan garisnya dimasukan ke dalam program mikrokontroler. Kemudian, prototipe digunakan untuk mengukur kekeruhan dari larutan standar dan penunjukan kekeruhannya dicatat. Apabila kekeruhannya masih tidak mendekati kekeruhan dari larutan standar kekeruhan, kurva kalibrasi kembali dibuat antara kekeruhan standar (sumbu $\mathrm{x}$ ) dan penunjukan kekeruhan (sumbu y), lalu persamaan garisnya dimasukkan ke dalam program mikrokontroler dan prototipe kembali digunakan untuk mengukur kekeruhan larutan standar. Apabila penunjukan kekeruhan masih tidak mendekati kekeruhan larutan standar, langkah terakhir diulangi kembali hingga penunjukan kekeruhan telah mendekati kekeruhan larutan standar. Setelah penunjukan kekeruhan telah mendekati kekeruhan larutan standar, tingkat akurasi, presisi dan histerisis dari sensor kekeruhan dilakukan dengan pengukuran kekeruhan larutan standar. Penentuan tingkat akurasi sensor kekeruhan ditentukan 
dari selisih penunjukan kekeruhan dan kekeruhan larutan standar [30], sedangkan tingkat presisinya ditentukan dari nilai RSD [31]. Setiap pengukuran dalam kalibrasi semua sensor tersebut dilakukan sebanyak 30 kali. Selama proses kalibrasi tersebut, sensor kekeruhan harus dijaga tetap kering agar penunjukan tegangan keluaran sensor tidak berubah.

Pada tahap ketiga, tingkat akurasi meter air pada berbagai kekeruhan dari air uji ditentukan dengan prototipe terhadap meter air elektronik tipe vertikal (K-24 Water Flowmeter). Air uji yang disiapkan terdiri dari 5 liter air bersih, hasil saringan dari campuran air bersih dan tanah ( 5 liter air bersih +10 gram tanah, 5 liter air bersih +20 gram tanah). Pengujian pertama dilakukan dengan air uji dari air bersih dengan cara memasukan dan mengalirkan air dari wadah atas menuju meter air uji lalu air uji ditampung dan ditimbang dengan prototipe. Volume air dihitung dari hasil bagi massa air yang ditimbang dengan densitas terukur dari prototipe. Sebagai pembanding, densitas air uji juga diukur dengan hidrometer (Alla France Hydrometer $0,700-2,000 \mathrm{~g} / \mathrm{cm}^{3}$ ). Kemudian, volume air juga dihitung dari hasil bagi massa air terukur dengan densitas dari hidrometer. Nilai kesalahan meter uji ditentukan dengan cara membandingkan volume air yang ditimbang dan volume meter air uji (selisih penunjukan akhir dan penunjukan awal). Nilai kesalahan yang didapatkan dari volume air dari densitas terukur prototipe dan volume dari densitas hidrometer kemudian dibandingkan. Langkah yang sama dilakukan dengan air uji yang dibuat dari saringan campuran air dan tanah.

\section{Hasil dan Pembahasan}

Hasil pembuatan prototipe instalasi uji meter air untuk pengujian parameter kekeruhan ditunjukan pada Gambar 3(a). Sensor level/volume, sensor suhu, dan sensor kekeruhan ditempatkan untuk mengukur kondisi air uji di wadah atas. Sebagian air uji dicuplik dan diukur kekeruhannya untuk menjaga sensor kekeruhan tidak terkena air pada saat air uji dimasukan ke dalam wadah atas. Sedangkan, kondisi air uji di wadah bawah diukur oleh sensor loadcell dan sensor suhu. Contoh hasil pengukuran kondisi air uji ditunjukan pada Gambar 3(b). Seperti ditunjukan pada Gambar 3(b), volume air pada wadah atas sebesar 4540,8 ml karena sebagian air uji dipakai untuk pengukuran kekeruhan. Hasil pengukuran kekeruhan adalah 83,05 NTU dari sampel air uji (hasil saringan 5 liter air + 20 gram tanah).

Untuk memastikan hasil pengukuran prototipe akurat, sensor-sensor yang terdapat di dalam prototipe dikalibrasi. Hasil kalibrasi sensor loadcell ditunjukan pada Tabel 1 dan Tabel 2. Tabel 1 menunjukan hasil kalibrasi faktor kalibrasi dari sensor load cell dengan hasil nilai faktor kalibrasi 285,0 yang dapat memberikan penunjukan paling mendekati massa anak timbangan $1 \mathrm{~kg}$. Faktor kalibrasi merupakan faktor koreksi dari sensor load cell yang membuat sensor dapat menunjukan nilai pengukuran yang sesuai atau mendekati nilai anak timbangan yang ditimbang [32]. Dengan hasil pada Tabel 1, faktor kalibrasi sebesar 285,0 kemudian digunakan untuk kalibrasi sensor load cell dan hasilnya ditunjukan pada Tabel 2. Tingkat akurasi dan presisi dari sensor load cell sangat tinggi dengan nilai sebesar 99,8\% dan 99,9\%. Selain itu, kecilnya nilai histerisis sebesar -2,05 gram untuk penunjukan anak timbangan maksimum $5 \mathrm{~kg}$ menunjukan sensor load cell pada prototipe telah bekerja sangat konsisten baik pada kondisi pengukuran naik maupun pada pengukuran turun [33]. 

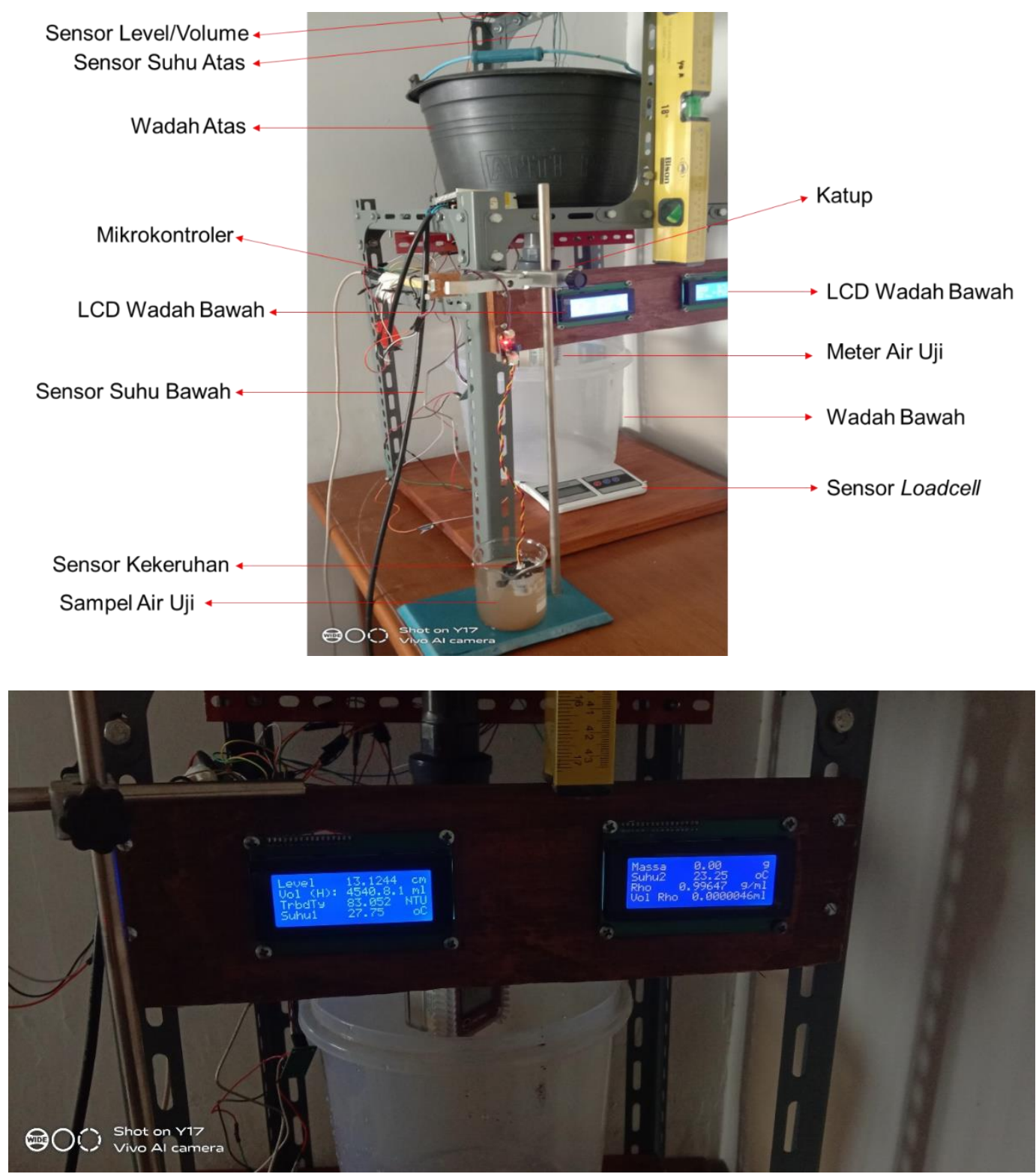

Gambar 3. Hasil pembuatan prototipe instalasi uji meter air (a) dan contoh hasil pengukuran (b)

Tabel 1. Hasil kalibrasi faktor kalibrasi sensor load cell

\begin{tabular}{ccc}
\hline No. & Faktor Kalibrasi & Penunjukan Massa Rata-Rata $(\mathrm{g})$ \\
\hline 1. & 428,2 & 694,4 \\
2. & 264,1 & 1123,8 \\
3. & 285,0 & 998,3 \\
\hline
\end{tabular}

Tabel 2. Hasil kalibrasi sensor load cell

\begin{tabular}{ccccccc}
\hline No. & $\begin{array}{c}\text { Massa } \\
\text { Nominal (g) }\end{array}$ & $\begin{array}{c}\text { Nilai Rata- } \\
\text { Rata (g) }\end{array}$ & $\begin{array}{c}\text { Standar } \\
\text { Deviasi }(\mathrm{g})\end{array}$ & $\begin{array}{c}\text { Akurasi } \\
(\%)\end{array}$ & $\begin{array}{c}\text { Presisi } \\
(\%)\end{array}$ & $\begin{array}{c}\text { Histerisis } \\
(\mathrm{g})\end{array}$ \\
\hline 1 & 1000 & 998,25 & 0,50 & 99,74 & 99,85 & $-4,55$ \\
2 & 2000 & 1997,52 & 1,28 & 99,68 & 99,81 & $-5,33$ \\
\hline
\end{tabular}




\begin{tabular}{ccccccc}
\hline 3 & 3000 & 2998,44 & 0,82 & 99,89 & 99,92 & $-0,21$ \\
4 & 4000 & 3996,18 & 0,33 & 99,90 & 99,98 & $-0,57$ \\
5 & 5000 & 4994,42 & 0,39 & 99,88 & 99,98 & 0,42 \\
6 & 5000 & 4994,00 & 0,55 & 99,86 & 99,97 & \\
7 & 4000 & 3996,75 & 1,57 & 99,82 & 99,88 & \\
8 & 3000 & 2998,65 & 3,35 & 99,64 & 99,67 & \\
9 & 2000 & 2002,86 & 0,79 & 99,98 & 99,88 & \\
10 & 1000 & 1002,81 & 0,45 & 99,78 & 99,87 & \\
\hline \multicolumn{7}{c}{ Rata-rata } \\
\hline
\end{tabular}

Hasil kalibrasi sensor suhu ditunjukan pada Tabel 3. Dua unit sensor suhu baik pada wadah atas (Termokopel Atas) maupun pada wadah bawah (Termokopel Bawah) menunjukan hasil pengukuran suhu yang berdekatan dengan suhu dari termometer standar yaitu $\left(-0,2^{\circ} \mathrm{C}\right.$ dan $\left.-0,5^{\circ} \mathrm{C}\right)$ dengan standar deviasi sebesar $0,16{ }^{\circ} \mathrm{C}$ dan 0,12 ${ }^{\circ} \mathrm{C}$. Dengan selisih pengukuran yang cukup dekat, dua unit sensor suhu tersebut menunjukan tingkat akurasi dan presisi yang tinggi yaitu 95,3\% dan 95,3\% untuk Termokopel Bawah, serta 97,2\% dan 96,5\% untuk Termokopel atas. Kalibrasi tersebut dilakukan pada satu titik yaitu $10^{\circ} \mathrm{C}$ dikarenakan kalibrasi termokopel juga dapat dilakukan pada keadaan satu suhu [34], dan media kalibrasi telah mencapai keadaan isotermal [35].

Tabel 3. Hasil kalibrasi sensor suhu

\begin{tabular}{ccccc}
\hline Parameter & $\begin{array}{c}\text { Termokopel } \\
\text { Bawah }\end{array}$ & $\begin{array}{c}\text { Termometer } \\
\text { Standar }\end{array}$ & $\begin{array}{c}\text { Termokopel } \\
\text { Atas }\end{array}$ & $\begin{array}{c}\text { Termometer } \\
\text { Standar }\end{array}$ \\
\hline Suhu benar $\left({ }^{\circ} \mathrm{C}\right)$ & & 9,9 & & 10,4 \\
Suhu rata-rata $\left({ }^{\circ} \mathrm{C}\right)$ & 9,92 & & 10,45 & \\
Standar deviasi $\left({ }^{\circ} \mathrm{C}\right)$ & 0,16 & & 0,12 & \\
Akurasi $(\%)$ & 95,34 & 96,29 & \\
Akurasi Rata-Rata $(\%)$ & & \multicolumn{3}{c}{96,52} \\
Presisi $(\%)$ & 95,26 & 95,89 & \\
Presisi rata-rata $(\%)$ & & \multicolumn{3}{c}{} \\
\hline
\end{tabular}

Hasil kalibrasi sensor ultrasonik HC-SR04 sebagai sensor ketinggian dan sensor volume ditunjukan pada Tabel 4 hingga Tabel 6. Sebagai sensor ketinggian [36], sensor ini memiliki akurasi dan presisi yang sangat baik yaitu 97,8\% dan 99,9\%. Hasil ini konsisten dengan tingkat kesalahan rata-rata dari pengukuran ketinggian air dengan sensor ultrasonik HC-SR04 yaitu sebesar 2,5\% [36]. Dengan hasil tersebut, sensor ini kemudian digunakan untuk mengukur ketinggian air pada saat berbagai volume air ditambahkan pada wadah atas prototipe. Hasil pengamatan ketinggian cairan tersebut ditunjukan pada Tabel 5, kemudian dengan menempatkan data ketinggian air sebagai sumbu $\mathrm{x}$ dan volume air sebagai sumbu y maka kurva kalibrasi volume air terhadap ketinggian air dapat dibuat (Gambar 4). Pada Gambar 4, hubungan antara volume air terhadap ketinggian air berupa persamaan regresi linear $\mathrm{y}=497,97 \mathrm{x}-1864,3$ dengan nilai $\mathrm{R}^{2}=0,9917$ dan memenuhi kriteria linearitas [37](Saputra, 2013). Kemudian dengan persamaan garis tersebut, sensor digunakan untuk mengukur volume air yang ditambahkan ke 
dalam prototipe dan hasilnya ditunjukan pada Tabel 6. Sensor tersebut dapat menunjukan pengukuran volume yang mendekati volume air sebenarnya dengan nilai akurasi dan presisi sebesar $95,4 \%$ dan $93,6 \%$.

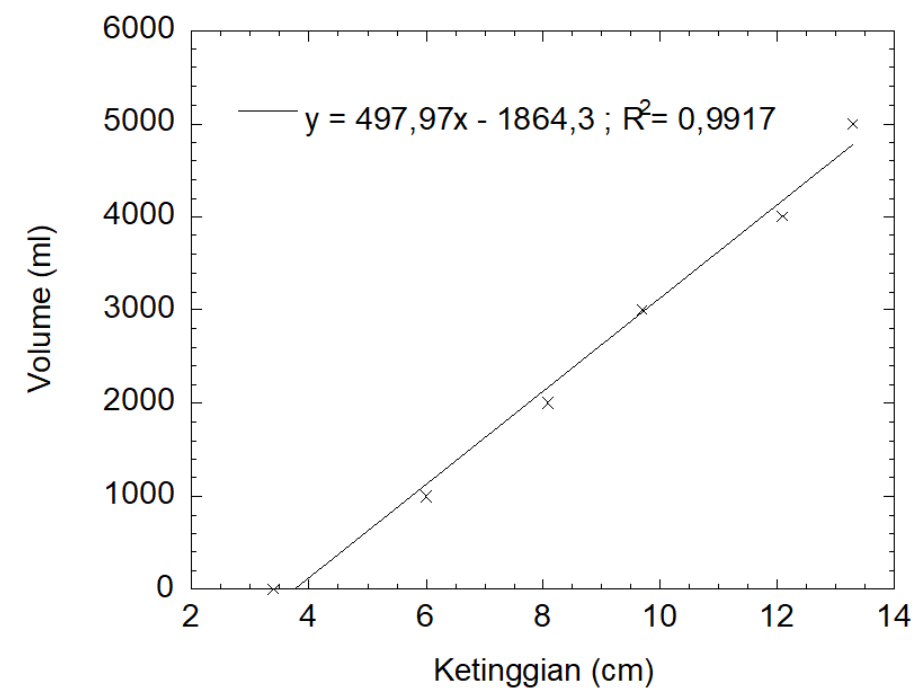

Gambar 4. Kurva kalibrasi volume terhadap ketinggian

Tabel 4. Hasil kalibrasi sensor ketinggian

\begin{tabular}{ccccccc}
\hline No. & Ketinggian $(\mathrm{cm})$ & $\begin{array}{c}\text { Ketinggian rata- } \\
\text { rata }(\mathrm{cm})\end{array}$ & $\begin{array}{c}\text { Standar deviasi } \\
(\mathrm{cm})\end{array}$ & $\begin{array}{c}\text { Akurasi } \\
(\%)\end{array}$ & $\begin{array}{c}\text { Presisi } \\
(\%)\end{array}$ & $\begin{array}{c}\text { Error } \\
(\%)\end{array}$ \\
\hline 1. & 5,0 & 5,3 & 0,0 & 95,0 & 100,0 & $-5,0$ \\
2. & 7,0 & 7,3 & 0,0 & 96,0 & 100,0 & $-4,0$ \\
3. & 9,0 & 9,1 & 0,0 & 98,9 & 100,0 & $-1,1$ \\
4. & 11,0 & 11,0 & 0,0 & 100,0 & 100,0 & 0,0 \\
5. & 13,0 & 13,3 & 0,0 & 97,7 & 100,0 & $-2,3$ \\
6. & 43,0 & 43,1 & 0,1 & 99,4 & 99,1 & 0,6 \\
\hline \multicolumn{7}{r}{} \\
\hline
\end{tabular}

Hasil kalibrasi sensor kekeruhan ditunjukan pada Tabel 7 hingga Tabel 10 . Kalibrasi sensor kekeruhan dimulai dengan pengukuran tegangan keluaran dari berbagai kekeruhan dengan Larutan Standar 0 NTU, 100 NTU dan 400 NTU. Hasilnya ditunjukan pada Tabel 7, kemudian dibuat menjadi kurva kalibrasi tegangan terhadap kekeruhan dengan persamaan garis yang ditunjukan pada Tabel 8 yaitu y $=0,0026 x+3,7979$ dan nilai $R 2=0,9916$ (Pengamatan ke 0 ). Selanjutnya, persamaan garis tersebut diolah menjadi $\mathrm{x}=(3,7979$-voltage $) / 0,0026$ agar dapat menentukan kekeruhan dari tegangan sensor. Hasil pengukuran kekeruhan dengan persamaan Pengamatan ke 0 ditunjukan pada Tabel 9. Karena penunjukan kekeruhannya masih jauh dari nilai kekeruhan larutan standar yaitu -321,55 NTU; -293,37 NTU dan 168,63 NTU yang merupakan Pengamatan I pada Tabel 9, maka tiga nilai penunjukan kekeruhan tersebut kemudian dibuat menjadi kurva kalibrasi penunjukan kekeruhan terhadap kekeruhan standar dan hasilnya berupa persamaan garis $\mathrm{y}=1,298 \mathrm{x}-365,1$ yang kemudian diubah menjadi $\mathrm{x}=(\mathrm{y}+365,1) / 1,298$ dan $\mathrm{y}$ disubtitusi dengan persamaan $\mathrm{x}$ dari Pengamatan ke 0 , karena penunjukan 
kekeruhannya didapatkan dari pengukuran tegangan keluaran pada Pengamatan ke 0 , sehingga persamaan yang dimasukan ke dalam program mikrokontroler adalah $\mathrm{x}$ $=((((3,7979$-voltage $) / 0,0026)+365,1) / 1,298)$ seperti ditunjukan pada Tabel 8 . Kemudian, hasil pengukuran kekeruhannya ditunjukan pada Tabel 9 sebagai Pengamatan II dengan penunjukan kekeruhan yang lebih mendekati nilai kekeruhan larutan standar.

Tabel 5. Hasil pengamatan ketinggian cairan dari berbagai volume air yang ditambahkan

\begin{tabular}{cc}
\hline Volume $(\mathrm{ml})$ & Ketinggian Rata-rata $(\mathrm{cm})$ \\
\hline 0 & 3,4 \\
1000 & 6,0 \\
2000 & 8,1 \\
3000 & 9,7 \\
4000 & 12,1 \\
5000 & 13,3 \\
\hline
\end{tabular}

Tabel 6. Hasil kalibrasi sensor volume

\begin{tabular}{ccccccccc}
\hline No. & $\begin{array}{c}\text { Volume } \\
(\mathrm{ml})\end{array}$ & $\begin{array}{c}\text { Vol. } \\
\text { rata- } \\
\text { rata } \\
(\mathrm{ml})\end{array}$ & $\begin{array}{c}\text { Error } \\
(\mathrm{ml})\end{array}$ & $\begin{array}{c}\text { Standar } \\
\text { deviasi } \\
(\mathrm{ml})\end{array}$ & $\begin{array}{c}\text { Bias } \\
(\mathrm{ml})\end{array}$ & $\begin{array}{c}\text { Standar } \\
\text { Deviasi } \\
(\mathrm{ml})\end{array}$ & $\begin{array}{c}\text { Akurasi } \\
(\%)\end{array}$ & $\begin{array}{c}\text { Presisi } \\
(\%)\end{array}$ \\
\hline 1 & 1000,0 & 1113,8 & 113,8 & 19,5 & $-113,8$ & 19,5 & 94,5 & 94,2 \\
2 & 2000,0 & 2046,4 & 46,4 & 94,0 & $-46,4$ & 94,0 & 88,2 & 85,9 \\
3 & 3000,0 & 3128,7 & 128,7 & 66,8 & $-128,7$ & 66,8 & 97,6 & 93,3 \\
4 & 4000,0 & 4086,9 & 86,9 & 65,1 & $-86,9$ & 65,1 & 97,3 & 95,1 \\
5 & 5000,0 & 5003,8 & 3,8 & 9,3 & $-3,8$ & 9,3 & 99,5 & 99,4 \\
\hline \multicolumn{7}{c}{ Rata-rata } \\
\hline
\end{tabular}

Tabel 7. Hasil pengukuran tegangan keluaran sensor kekeruhan

\begin{tabular}{ccc}
\hline No. & Kekeruhan Larutan Standar (NTU) & Tegangan Keluaran Rata-Rata (V) \\
\hline 1. & 0 & 3,76 \\
2. & 100 & 3,59 \\
3. & 400 & 2,74 \\
\hline
\end{tabular}

Tabel 8. Hasil kurva kalibrasi dari sensor kekeruhan

\begin{tabular}{|c|c|c|c|c|c|c|}
\hline No & $\begin{array}{l}\text { Peng- } \\
\text { amatan }\end{array}$ & Sumbu X & Sumbu Y & $\begin{array}{c}\text { Persamaan } \\
\text { Garis }\end{array}$ & $\begin{array}{l}\text { Nilai } \\
\mathrm{R}^{2}\end{array}$ & Persamaan di dalam mikrokontroler \\
\hline 1. & 0 & Kekeruhan & Tegangan & $\begin{array}{c}\mathrm{Y}=- \\
0,0026 \mathrm{X}+ \\
3,7979\end{array}$ & 0,9916 & $X=(3,7979$-voltage $) / 0,0026$ \\
\hline 2. & I & $\begin{array}{c}\text { Kekeruhan } \\
\text { Standar }\end{array}$ & $\begin{array}{l}\text { Penunjukan } \\
\text { Kekeruhan }\end{array}$ & $\begin{aligned} Y & =1,298 X \\
& -365,1\end{aligned}$ & 0,9638 & $\begin{array}{c}X=((((3,7979- \\
\text { voltage }) / 0,0026)+365,1) / 1,298)\end{array}$ \\
\hline 3. & II & $\begin{array}{c}\text { Kekeruhan } \\
\text { Standar }\end{array}$ & $\begin{array}{l}\text { Penunjukan } \\
\text { Kekeruhan }\end{array}$ & $\begin{array}{c}\mathrm{Y}= \\
1,0654 \mathrm{X}- \\
24,982\end{array}$ & 0,9902 & $\begin{array}{c}\mathrm{X}=((((((3,7979- \\
\text { voltage }) / 0,0026)+365,1) / 1,298) \\
+24,982) / 1,0654)\end{array}$ \\
\hline
\end{tabular}




\begin{tabular}{cccccc}
\hline 4. III & Kekeruhan & Penunjukan & $\mathrm{Y}=$ & 0,9899 & $\mathrm{X}=(((()(((3,7979-$ \\
& Standar & Kekeruhan & $1,0078 \mathrm{X}-$ & & voltage $) / 0,0026)+365,1) / 1,298)$ \\
& & 0,9708 & & $+24,982) / 1,0654)+0,9708) / 1,0078)$ \\
\hline
\end{tabular}

Karena masih teramati nilai negatif kekeruhan Larutan 0 NTU, maka regresi linear, input persamaan dan pengukuran kekeruhan larutan standar kembali diulang seperti langkah sebelumnya. Hasilnya berupa penunjukan kekeruhan sebesar 16,63 NTU; 76,34 NTU dan 408,03 NTU yang lebih mendekati nilai kekeruhan larutan standar seperti ditunjukan sebagai Pengamatan III pada Tabel 9. Untuk memperbaiki penunjukan kekeruhan, langkah regresi linear, input persamaan dan pengukuran kekeruhan larutan standar kembali dilakukan. Hasilnya berupa penunjukan kekeruhan sebesar 16,90 NTU; 80,98 NTU dan 406,95 NTU teramati dan dituliskan sebagai Pengamatan IV pada Tabel 9. Karena nilai kekeruhan pada Pengamatan III dan Pengamatan IV sudah tidak berubah signifikan, maka kalibrasi sensor kekeruhan diakhiri dan data Pengamatan IV diambil sebagai data pengukuran naik dan data pengukuran turun dari Larutan Standar 400 NTU hingga Larutan 0 NTU digabung untuk perhitungan nilai histerisis seperti ditunjukan pada Tabel 10.

Tabel 9. Hasil pengukuran kekeruhan dari larutan standar

\begin{tabular}{cccccc}
\hline No. & Larutan & & \multicolumn{2}{c}{ Kekeruhan Rata-Rata (NTU) } & \\
& $\begin{array}{c}\text { Standar } \\
\text { (NTU) }\end{array}$ & Pengamatan I & Pengamatan II & Pengamatan III & Pengamatan IV \\
& 0 & $-321,55$ & $-6,58$ & 16,63 & 16,90 \\
1. & 100 & $-293,37$ & 57,03 & 76,34 & 80,98 \\
2. & 400 & 168,63 & 407,32 & 408,03 & 406,95 \\
\hline 3. & & & & & \\
\hline
\end{tabular}

Tabel 10. Hasil kalibrasi dari sensor kekeruhan

\begin{tabular}{|c|c|c|c|c|c|c|}
\hline \multirow[b]{2}{*}{ No. } & \multirow{2}{*}{$\begin{array}{c}\text { Standar } \\
\text { Kekeruhan } \\
(\mathrm{NTU})\end{array}$} & \multirow{2}{*}{$\begin{array}{c}\text { Penunjukan } \\
\text { Kekeruhan Rata-rata } \\
\text { (NTU) }\end{array}$} & \multicolumn{3}{|c|}{ Kesalahan } & \multirow[b]{2}{*}{$\begin{array}{c}\text { Histerisis } \\
\text { (NTU) }\end{array}$} \\
\hline & & & $\begin{array}{c}\text { Kesalahan } \\
\text { (NTU) }\end{array}$ & $\begin{array}{c}\text { Relatif } \\
(\%)\end{array}$ & $\begin{array}{l}\text { RSD } \\
(\%)\end{array}$ & \\
\hline 1 & 0 & 16,90 & 16,90 & 4,23 & 6,45 & 0,29 \\
\hline 2 & 100 & 80,98 & $-19,02$ & $-4,75$ & 1,89 & $-3,98$ \\
\hline 3 & 400 & 406,95 & 6,95 & 1,74 & 0,33 & 2,09 \\
\hline 4 & 400 & 404,86 & 4,86 & 1,21 & 0,42 & \\
\hline 5 & 100 & 84,96 & $-15,04$ & $-3,76$ & 2,22 & \\
\hline \multirow[t]{2}{*}{6} & 0 & 16,62 & 16,62 & 4,15 & 7,37 & \\
\hline & & Rata-rata & 1,88 & 0,47 & 3,11 & $-0,54$ \\
\hline
\end{tabular}

Penentuan akurasi dan presisi dari sensor kekeruhan tidak dapat dilakukan melalui nilai bias dan standar deviasi [28]. Hal ini dikarenakan ada nilai 0 NTU sebagai nilai benar yang akan menyebabkan nilai (bias+3xstandar deviasi)/x_benar menjadi bernilai tak hingga untuk perhitungan akurasi dan tingkat kesalahan; begitu juga nilai $3 \times$ standar deviasi/x_benar pada perhitungan nilai presisi yang juga akan menghasilkan nilai tak hingga. Oleh karenanya, tingkat akurasi dihitung dari nilai kesalahan sebagai selisih antara nilai penunjukan dan nilai standar [30] dan kesalahan relatif dengan membagi nilai kesalahan dengan nilai kekeruhan maksimum yaitu 400 NTU. Hasil perhitungan menunjukan kesalahan rata-rata dan 
kesalahan relatif sensor kekeruhan adalah sebesar 1,88 NTU dan 0,47\%. Nilai kesalahan yang cukup besar pada Larutan 0 NTU tersebut menyerupai hasil pengukuran kekeruhan dengan sensor fotodioda [3]. Dengan alasan yang sama dengan pada penentuan tingkat akurasi, nilai kepresisian sensor kekeruhan ditentukan melalui nilai RSD dan hasilnya menunjukan rata-rata RSD sensor kekeruhan adalah sebesar 3,11\% dan memenuhi persyaratan presisi dengan nilai RSD lebih dari $2 \%$ [31].

Tabel 11. Hasil uji meter air uji dihitung dari densitas terukur dan densitas hidrometer

\begin{tabular}{|c|c|c|c|c|c|c|c|c|c|}
\hline No. & $\begin{array}{l}\text { Vol. Meter } \\
\text { Air Uji } \\
(\mathrm{ml})\end{array}$ & $\begin{array}{l}\text { Massa } \\
\text { Air }(\mathrm{g})\end{array}$ & $\begin{array}{c}\text { Densitas } \\
\text { Terukur } \\
(\mathrm{g} / \mathrm{ml})\end{array}$ & $\begin{array}{c}\text { Vol. dari } \\
\text { Densitas } \\
\text { Terukur } \\
\quad(\mathrm{ml})\end{array}$ & $\begin{array}{c}\text { Error } \\
\text { Vol. } \\
\text { Densitas } \\
\text { Terukur } \\
(\%) \\
\end{array}$ & $\begin{array}{l}\text { Den- } \\
\text { sitas } \\
\text { Hidro- } \\
\text { meter } \\
(\mathrm{g} / \mathrm{ml})\end{array}$ & $\begin{array}{c}\text { Vol. dari } \\
\text { Densitas } \\
\text { Hidro- } \\
\text { meter (ml) }\end{array}$ & $\begin{array}{c}\text { Error } \\
\text { Vol. } \\
\text { Hidro- } \\
\text { meter } \\
(\%) \\
\end{array}$ & $\begin{array}{l}\text { Ke- } \\
\text { keruh- } \\
\text { an } \\
\text { (NTU) }\end{array}$ \\
\hline \multicolumn{10}{|c|}{ Air Uji I : 5 Liter Air Bersih } \\
\hline 1 & 5450 & 5426,9 & 0,99426 & 5458,2 & $-0,2$ & 1,00 & 5426,9 & 0,4 & 17,11 \\
\hline 2 & 5477 & 5426,3 & 0,99637 & 5446,1 & 0,6 & 1,00 & 5426,3 & 0,9 & 17,11 \\
\hline \multirow[t]{2}{*}{3} & 5464 & 5390,2 & 0,99604 & 5411,6 & 1,0 & 1,00 & 5390,2 & 1,4 & 17,11 \\
\hline & & & \multicolumn{2}{|c|}{ Rata-rata } & 0,5 & \multicolumn{2}{|c|}{ Rata-rata } & 0,9 & \\
\hline \multicolumn{10}{|c|}{ Air Uji II: Hasil Saring (5 liter air bersih $+10 \mathrm{~g}$ tanah) } \\
\hline 1 & 5420 & 5224,0 & 0,99593 & 5245,3 & 3,3 & 1,01 & 5172,2 & 4,8 & 36,92 \\
\hline 2 & 5300 & 5189,1 & 0,99581 & 5211,0 & 1,7 & 1,01 & 5137,7 & 3,2 & 36,92 \\
\hline \multirow[t]{2}{*}{3} & 5180 & 4958,2 & 0,99581 & 4979,1 & 4,0 & 1,01 & 4909,1 & 5,5 & 36,92 \\
\hline & & & \multicolumn{2}{|c|}{ Rata-rata } & 3,0 & \multicolumn{2}{|c|}{ Rata-rata } & 4,5 & \\
\hline \multicolumn{10}{|c|}{ Air Uji III : Hasil Saring (5 liter air bersih $+20 \mathrm{~g}$ tanah) } \\
\hline 1 & 5530 & 5276,47 & 0,9957 & 5299,3 & 4,4 & 1,02 & 5173,0 & 6,9 & 95,62 \\
\hline 2 & 5530 & 5237,73 & 0,99616 & 5257,9 & 5,2 & 1,02 & 5135,0 & 7,7 & 95,62 \\
\hline \multirow[t]{2}{*}{3} & 5490 & 5234,01 & 0,99593 & 5255,4 & 4,5 & 1,02 & 5131,4 & 7,0 & 95,62 \\
\hline & & & \multicolumn{2}{|c|}{ Rata-rata } & 4,7 & \multicolumn{2}{|c|}{ Rata-rata } & 7,2 & \\
\hline
\end{tabular}

Dengan hasil kalibrasi yang baik dari setiap sensor di dalam prototipe (Tabel 1 hingga Tabel 10), maka prototipe siap digunakan untuk pengujian meter air untuk pengaruh parameter kekeruhan. Variasi kekeruhan dari air uji dilakukan dengan menambahkan massa tanah yang berbeda yaitu $10 \mathrm{~g}$ dan $20 \mathrm{~g}$ pada masing-masing air bersih sebanyak 5 liter. Campuran ini disaring untuk memisahkan dari partikel berukuran besar dan untuk memastikan yang teramati hanya kekeruhan. Hasil pengujian meter air uji pada berbagai kondisi air uji ditunjukan pada Tabel 11. Kenaikan kekeruhan terjadi pada saat air bersih ditambahkan dengan jumlah tanah yang lebih banyak yaitu dari 17,11 NTU (0 g tanah); 36,93 NTU (10 g tanah); dan 95,62 NTU (20 g tanah). Kenaikan kekeruhan tersebut menyebabkan kenaikan kesalahan pengukuran yaitu dari $0,5 \%$ menjadi $3,0 \%$ dan $4,7 \%$ yang dihitung dari densitas terukur sedangkan dengan densitas hidrometer, kenaikan kesalahan pengukuran teramati dari dari $0,9 \%$ menjadi $4,5 \%$ dan $7,2 \%$. Dua profil kenaikan kesalahan tersebut juga digambarkan pada Gambar 5 yang keduanya menunjukan kesalahan yang lebih besar pada saat kekeruhan lebih tinggi. 


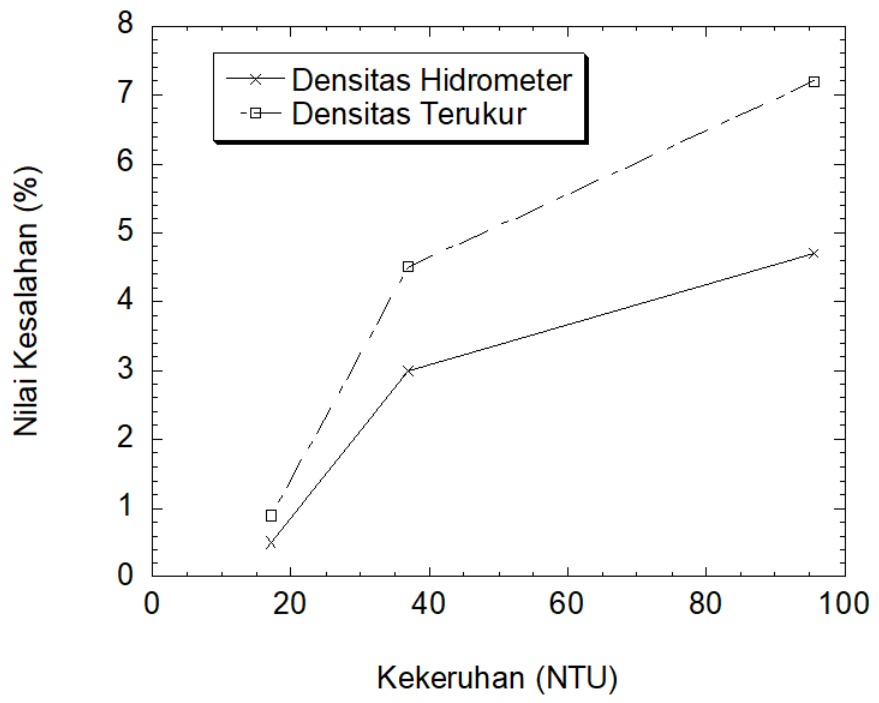

Gambar 5. Tingkat kesalahan meter air pada berbagai kekeruhan

Berdasarkan rumus kesalahan sebagai selisih penunjukan terhadap standar [30], pada kekeruhan lebih tinggi, penunjukan meter uji menjadi lebih tinggi dibandingkan pengukuran standar. Hal ini konsisten dengan kenaikan penunjukan meter air jenis single jet pada saat ditambahkan partikulat pasir pada kondisi laju alir rendah [15] dan kesalahan positif akibat partikulat [13], akan tetapi keduanya tidak menunjukan nilai kekeruhan dari partikulat tersebut [13], [15]. Meter air single jet dan meter air uji memiliki kesamaan menggunakan turbin sebagai elemen pengukur volume, akan tetapi meter air uji memiliki elemen penunjukan secara elektronik sedangkan meter air single jet memiliki elemen penunjukan analog. Dengan demikian, penelitian ini merupakan studi pertama tentang pengaruh kekeruhan campuran air-tanah terhadap meter air digital khususnya tipe vertikal [13], [15].

Gambar 5 juga menunjukan profil kenaikan kesalahan pengukuran pada saat menggunakan volume yang dihitung dari densitas hidrometer. Sebagai pembanding, seperti ditunjukan pada Tabel 11, hidrometer dapat mengukur kenaikan densitas air uji pada saat tanah yang ditambahkan dari $10 \mathrm{~g}$ menjadi $20 \mathrm{~g}$. Kenaikan densitas air uji tersebut diakibatkan oleh kenaikan jumlah padatan dalam cairan dalam larutan sehingga larutan menjadi lebih besar massanya. Hal ini konsisten dengan pengamatan kenaikan densitas sampel nira tebu akibat kenaikan fraksi padatan dibanding nira sorghoum [38]. Kenaikan densitas tersebut menyebabkan nilai volume standar semakin kecil sebagai hasil bagi massa terukur prototipe dengan densitas dari hidrometer, sehingga selisih volume meter uji terhadap volume standar semakin besar. Dengan pengukuran densitas hidrometer tersebut, efek kekeruhan yang menambah densitas air uji semakin terlihat dan semakin memperkecil volume standar, dan menyebabkan kesalahan pengukuran meter uji semakin besar pada kekeruhan lebih tinggi.

\section{Kesimpulan}

Prototipe instalasi uji meter air untuk pengujian parameter kekeruhan dapat direalisasikan menggunakan sensor loadcell, sensor suhu, sensor 
ketinggian/volume dan sensor kekeruhan. Hasil kalibrasi menunjukan sensorsensor tersebut memiliki tingkat akurasi dan presisi yang tinggi yaitu sensor loadcell 99,8\% dan 99,9\%; sensor volume 95,4\% dan 93,6\%; sensor suhu 96,3\% dan 95,9\%; dan sensor kekeruhan dengan tingkat kesalahan 0,5\% dan RSD 3,3\%. Pengujian akurasi meter air pada berbagai variasi kekeruhan dari air uji telah dilakukan. Dengan densitas terukur dari sensor suhu, kenaikan kekeruhan dari 17,11 NTU menjadi 36,92 NTU dan 95,62 NTU menyebabkan kenaikan kesalahan pengukuran dari 0,5\%; menjadi 3,0\% dan 4,7\%. Dengan kekeruhan yang sama, perhitungan volume dari densitas hidrometer, menyebabkan kenaikan kesalahan pengukuran dari $0,9 \%$ menjadi $4,5 \%$ dan 7,2\%. Hal ini konsisten dengan hasil studi kenaikan densitas dari kenaikan fraksi padatan di dalam larutan dan kenaikan kesalahan pengukuran pada jenis meter air dengan elemen pengukur volume dari turbin. Hasil penelitian ini menunjukan efek kekeruhan dari tanah terhadap kenaikan kesalahan pengukuran meter air yang memperkuat studi sebelumnya yang hanya mengenai efek partikel pengotor pada meter air

\section{Ucapan Terima Kasih}

Ucapan terima kasih disampaikan kepada Akademi Metrologi dan Instrumentasi Kementerian Perdagangan yang telah membiayai penelitian dalam Daftar Isian Pelaksanaan Anggaran (DIPA) Akademi Metrologi dan Instrumentasi Kementerian Perdagangan Republik Indonesia Nomor SP 090.01.1.423005/2020 tanggal 12 November 2019 dengan Nomor Kontrak 370/SJ-DAG.10/AKMET/KONTRAK/ $06 / 2020$

\section{Daftar Pustaka}

1. B. M. Natalia, Mardiyono, and A. Said, "Implementasi Program Zona Air Minum Prima (ZAMP) Untuk Memenuhi Kebutuhan Air Minum Masyarakat (Studi Pada PDAM Kota Malang),” J. Adm. Publik, vol. 2, no. 1, (2014), pp. $11-15$.

2. E. Rahmawati, Trisnaningsih, and Sudarmi, "Upaya Pemenuhan dan Pemanfaatan Air Bersih di Desa Rawa Ragil," J. Skripsi Fak. Kegur. dan Ilmu Pendidikan, Univ. Lampung, 2020.

3. M. Kautsar, R. R. Isnanto, and E. D. Widianto, "Sistem Monitoring Digital Penggunaan dan Kualitas Kekeruhan Air PDAM Berbasis Mikrokontroler ATMega328 Menggunakan Sensor Aliran Air dan Sensor Fotodiode," J. Teknol. dan Sist. Komput., vol. 3, no. 1, (2015), pp. 79-86.

4. H. Jaya, H. Winata, and I. Mariami, "Sistem Pendukung Keputusan Kelayakan Pembuatan Jaringan Baru Instalasi Pipa Air Untuk Distribusi Masyarakat Pada PDAM Tirtanadi Menggunakan Metode Moora," J. Teknol. Sist. Inf. dan Sist. Komput. TGD (J-SISKO TECH), vol. 3, no. 1, (2020), pp. 19-31.

5. D. Nababan, "Kajian Yuridis Terhadap Tera Meter Konsumen Perusahaan Daerah Air Minum (PDAM) di Tinjau dari Perspektif Perlindungan Konsumen (studi Pada Konsumen Perusahaan Daerah Air Minum Kota Pontianak)," J. Nestor Magister Huk., vol. 2, no. 4, (2013), pp. 1-30.

6. D. J. S. dan P. Konsumen, "Syarat Teknis Meter Air," Keputusan Direktur Jenderal Stand. dan Perlindungan Konsum., vol. 133/SPK/KE, 2015. 
7. Y. P. Heston and N. A. Pasawati, "Analisis Faktor Penyebab Kehilangan Air PDAM (PDAM Water Loss Factors Analysis)," Pros. Temu Ilm. IPLBI 2016, (2016), pp. 1-6,.

8. E. M. Lahengking, I. Elim, and R. Pusung, "Analisis Piutang Usaha Pada Perusahaan Daerah Air Minum (PDAM) Di Airmadidi Kabupaten Minahasa Utara," J. Ris. Akunt. Going Concern, vol. 12, no. 2, (2017), pp. 357-370.

9. Y. Arfah, "Analisis Kinerja Berbasis Balanced Scorecard Pada Perusahaan ( PDAM ) Tirta Bulian Kota Tebing Tinggi," Semin. Nas. Sains Teknol. Inf. 2019, (2019), pp. 185-189.

10. R. Wicaksono, "Pengaruh Pemisah Udara Pada Pembacaan Hasil Pengukuran Meter Air Digital Skala Rumah Tangga," UTOCRACY J. Otomasi, Kendali, dan Apl. Ind., vol. 4, no. 2, (2017), pp. 63-68.

11. O. I. D. M. Legale, "Water meters intended for the metering of cold potable water and hot water," (2006), Int. Recomm. OIML R 49-2.

12. I. G. S. Wiratama, Pengujian Meter Air Metode Volumetri Menggunakan Bejana Ukur Standar (BUS), 2018.

13. F. Arregui, E. C. Jr, R. Cobacho, and J. Garcia-Serra, "Key Factors Affecting Water Meter Accuracy," Leakage 2005-Conf. Proc., (2005), pp. 1-10.

14. H. E. Mutikanga, S. K. Sharma, and K. Vairavamoorthy, "Investigating water meter performance in developing countries: A case study of Kampala, Uganda,' Water SA, vol. 37, no. 4, (2011), pp. 567-574.

15. B. S. Buck, M. C. Johnson, and S. L. Barfuss, "Effects of particulates on water meter accuracy through expected life," J. Am. Water Works Assoc., vol. 104, no. 4, (2012), pp. E231-E242.

16. H. Puspitasari, "Pelayanan istribusi Air Bersih Di Perusahaan Daerah Air Minum Surakarta," Skripsi Jur. Ilmu Adm. Fak. Ilmu Sos. dan Ilmu Polit. Univ. Sebel. Maret Surakarta, (2009), pp. 1-98.

17. D. K. Fitri and S. P. Hadi, "Pengaruh Disiplin Kerja dan Motivasi terhadap Kinerja Pegawai pada Perusahaan Daerah Air Minum Tirta Amerta Kabupaten Blora Pendahuluan Perumusan Masalah," J. Ilmu Adm. Bisnis, vol. 5, no. 4, (2016), pp. 382-392.

18. C. Z. Myint, L. Gopal, and Y. L. Aung, "Reconfigurable smart water quality monitoring system in IoT environment," Proc. - 16th IEEE/ACIS Int. Conf. Comput. Inf. Sci. ICIS 2017, (2017), pp. 435-440.

19. T. I. Salim, H. S. Alam, R. P. Pratama, I. A. F. Anto, and A. Munandar, "ICACOMIT 2017: proceedings of the 2nd International Conference on Automation, Cognitive Science, Optics, Micro Electro-Mechanical System, and Information Technology : October 23rd, 2017, Jakarta, Indonesia," 2017 2nd Int. Conf. Autom. Cogn. Sci. Opt. Micro Electro-Mechanical Syst. Inf. Technol., (2017), pp. 34-40.

20. R. Pamuji, "Aplikasi Pencatatan Air Berbasis Smartphone Android," Diploma Thesis Univ. Komput. Indones., 2013.

21. G. K. Djoen, "Perancangan dan Pembuatan Meteran Air Digital," Skripsi Jur. Tek. Elektro Fak. Tek. Univ. Katolik Widya Mandala Surabaya, 2002.

22. Yaddarabullah and D. Lestari, "Perancangan Sistem Komunikasi Data Alat Pencatatan Meter," InfoTekJar (Jurnal Nas. Inform. dan Teknol. Jaringan), vol. 3, no. 1, (2018), pp. 49-54. 
23. A. Kasim and T. Ariyadi, "Prototipe Meteran Air Digital Berbasis Novoton Nuc Arm 120 sebagai Pembanding dengan Meteran Air Analog PDAM," J. Surya Energy, vol. 3, no. 1, (2018), pp. 248-254.

24. Y. Zhong et al., "An Easily Assembled Electromagnetic-Triboelectric Hybrid Nanogenerator Driven by Magnetic Coupling for Fluid Energy Harvesting and Self-Powered Flow Monitoring in a Smart Home/City," Adv. Mater. Technol., (2019), p. 1900741.

25. A. E. Keith and J. J. French, "Design and Testing of a Remote Deployable Water Purification System Powered by Solar Energy," Adv. Technol. Innov., vol. 4, no. 1, (2019), pp. 30-36.

26. F. E. Jones and G. L. Harris, "ITS-90 Density of Water Formulation for Volumetric Standards Calibration,” J. Res. Natl. Inst. Stand. Technol., vol. 97, no. 3, (1992), pp. 335-340.

27. E. Y. Sagas, F. Wenur, and L. C. C. E. Lengkey, "The study of the usage of cooler box with ice crust for the distribution of pak choi (Brassica rapa)," Cocos, vol. 6 , no. 15 , , (2015), pp. 1-10.

28. E. M. Mikhail and G. Gracie, Analysis and Adjustment of Survey Measurements. 1981.

29. Badan Standarisasi Nasional, "SNI 06-6989.25-2005: Cara uji Kekeruhan dengan Nefelometer," Standar Nas. Indones., (2005), pp. 1-9.

30. N. Amani and D. S. Arief, "Kalibrasi Jangka Sorong Nonius (Vernier Calliper) Berdasarkan Standar JIS B 7507 Di Laboratorium Pengukuran Teknik Mesin Universitas Riau," Jom Fteknik, vol. 2, no. 2, (2015), pp. 1-7.

31. W. Y. N. Syahfitri, Muhayatun, D. D. Lestiani, and N. Adventini, "Validasi Metode AAN untuk Analisis Unsur dalam Sampel Partikulat Udara," Pros. Semin. Nas. Sains dan Teknol. Nukl. PTNBR-BATAN Bandung 2009, (2009), pp. 221-226.

32. J. J. A. Basa et al., "Smart inventory management system for photovoltaicpowered freezer using wireless sensor network," Int. J. Emerg. Trends Eng. Res., vol. 7, no. 10, (2019),pp. 393-397.

33. H. Sulistyo and F. F. Akbar, "Prototipe Automatic Tank Gauging Optik untuk Pengukuran Level Fluida Statik," J. Otomasi Kontrol dan Instrumentasi, vol. 6, no. 2, (2014), p. 121.

34. M. D. Bethea and B. N. Rosenthal, "An Automated Thermocouple Calibration System,” IEEE Trans. Instrum. Meas., vol. 41, no. 5, (1992), pp. 702-706.

35. J. M. Lund, J. J. Parle, and M. R. Washburn, "Calibrated Isothermal Assembly For A Thermocouple Thermometer," (2001), US Patent 6293700 B1.

36. H. Purwanto, M. Riyadi, D. W. W. Astuti, and I. W. A. W. Kusuma, "Komparasi Sensor Ultrasonik HC-SR04 Dan JSN-SR04T Untuk Apikasi Sistem Deteksi Ketinggian Air,” J. SIMETRIS, vol. 10, no. 2, (2019), pp. 717724.

37. H. Saputra and M. Yusfi, "Rancang Bangun Alat Ukur Regangan Menggunakan Sensor Strain Gauge Berbasis Mikrikontroler Atmega8535 Dengan Tampilan LCD," J. Fis. Unand, vol. 2, no. 3, (2013), pp. 162-169.

38. D. Y. Ali, S. S. Yuwono, and N. Istianah, "Penjernihan Nira Tebu Dan Nira Sorgum Menggunakan Proses Sentrifugasi Dengan Penambahan Adsorben," J. Ilmu Pangan dan Has. Pertan., vol. 2, no. 1, (2018), pp. 63-71 